Hydrol. Earth Syst. Sci., 15, 1459-1471, 2011

www.hydrol-earth-syst-sci.net/15/1459/2011/

doi:10.5194/hess-15-1459-2011

(C) Author(s) 2011. CC Attribution 3.0 License.

\title{
Uncertainty in climate change projections of discharge for the Mekong River Basin
}

\author{
D. G. Kingston ${ }^{1,2}$, J. R. Thompson ${ }^{1}$, and G. Kite ${ }^{3}$ \\ ${ }^{1}$ UCL Department of Geography, University College London, Gower Street, London, WC1E 6BT, UK \\ ${ }^{2}$ Department of Geography, University of Otago, P.O. Box 56, Dunedin, New Zealand \\ ${ }^{3}$ Bryn Eithin, Cefn Bychan Road, Pantymwyn, Flintshire, CH7 5EN, UK
}

Received: 6 August 2010 - Published in Hydrol. Earth Syst. Sci. Discuss.: 23 August 2010

Revised: 29 April 2011 - Accepted: 4 May 2011 - Published: 13 May 2011

\begin{abstract}
The Mekong River Basin is a key regional resource in Southeast Asia for sectors that include agriculture, fisheries and electricity production. Here we explore the potential impacts of climate change on freshwater resources within the river basin. We quantify uncertainty in these projections associated with GCM structure and climate sensitivity, as well as from hydrological model parameter specification. This is achieved by running patternscaled GCM scenarios through a semi-distributed hydrological model (SLURP) of the basin. Pattern-scaling allows investigation of specific thresholds of global climate change including the postulated $2{ }^{\circ} \mathrm{C}$ threshold of "dangerous" climate change. Impacts of a $2{ }^{\circ} \mathrm{C}$ rise in global mean temperature are investigated using seven different GCMs, providing an implicit analysis of uncertainty associated with GCM structure. Analysis of progressive changes in global mean temperature from 0.5 to $6^{\circ} \mathrm{C}$ above the 1961-1990 baseline (using the $\mathrm{HadCM} 3 \mathrm{GCM}$ ) reveals a relatively small but non-linear response of annual river discharge to increasing global mean temperature, ranging from a $5.4 \%$ decrease to $4.5 \%$ increase. Changes in mean monthly river discharge are greater (from $-16 \%$ to $+55 \%$, with greatest decreases in July and August, greatest increases in May and June) and result from complex and contrasting intra-basin changes in precipitation, evaporation and snow storage/melt. Whilst overall results are highly GCM dependent (in both direction and magnitude), this uncertainty is primarily driven by differences in GCM projections of future precipitation. In contrast, there is strong consistency between GCMs in terms of both increased potential evapotranspiration and a shift to an earlier
\end{abstract}

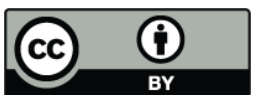

Correspondence to: D. G. Kingston (daniel.kingston@geography.otago.ac.nz) and less substantial snowmelt season. Indeed, in the upper Mekong (Lancang sub-basin), the temperature-related signal in discharge is strong enough to overwhelm the precipitationrelated uncertainty in the direction of change in discharge, with scenarios from all GCMs leading to increased river flow from April-June and decreased flow from July-August.

\section{Introduction}

Changing availability of freshwater resources is likely to be one of the most important consequences of projected 21 st century climate change, critically affecting the potential for sustainable development of life and livelihoods (Bates et al., 2008; Todd et al., 2011). The most recent projections presented by the Intergovernmental Panel on Climate Change (IPCC) suggest annual precipitation for the 2080 2099 period in the Southeast Asia region will be greater than the baseline 1980-1999 period, with changes of up to $10 \%$ over the Mekong Basin (Christensen et al., 2007). The middle half of the distribution of 21 GCMs in the IPCC report show changes in precipitation over this region of the same sign, making it an area of comparatively consistent precipitation projections (Christensen et al., 2007).

The impacts of hydrological changes resulting from projected changes in climate may be particularly severe for the Mekong River system given its role as a vital regional resource, providing food, water, transport and livelihoods (Kite, 2001). The Mekong also supports unique and varied ecosystems, with a number of endemic species and large and diverse fisheries. Ecosystem functioning is important because the Mekong (in part, through its fisheries) provides the staple diet for approximately 300 million people (MRC, 2003). Particularly productive areas include the Mekong

Published by Copernicus Publications on behalf of the European Geosciences Union. 
Delta and its associated wetlands, as well as the Tonle Sap in Cambodia. However, fisheries and other resources provided by the river are vulnerable to changes in the seasonality of river flow, sediment load and water quality (MRC, 2003). Indeed, fish catches per fisher have been declining over time, although there is some uncertainty as to whether this is, at least in part, due to increasing numbers of fishers (MRC, 2003). The Mekong is also being impacted by large-scale hydraulic interventions with a focus on hydropower. Four large dams have already been constructed on the Chinese section of the river and further dams are either under construction or planned throughout the river basin (Kite, 2001; Li and He, 2008; Stone, 2010; Wang et al., 2011). These dams have already been controversial in terms of their downstream impacts with uncertainty over their influence on recent variations in flow volumes, sediment loadings and fisheries (Kummu et al., 2010; $\mathrm{Li}$ and $\mathrm{He}, 2008$; Wang et al., 2011).

Given the magnitude of projected climatic changes, the importance of water for socio-economic development throughout the region (including the growing influence of hydropower), and the increasing (often trans-boundary) competition for water use in the Mekong, there is a clear need for improved understanding of the potential impacts of climate change on future availability of freshwater resources. Only through such understanding can water resource managers (particularly the basin authority, the Mekong River Commission, MRC) fully evaluate proposed developments and implement appropriate trans-boundary management strategies. The need for climate change adaptation strategies is particularly prescient for the Mekong given the reliance on the river for agriculture and fish, the vulnerability of the low-lying delta region including large flood-prone areas, and the relative absence of river management infrastructure. This situation is likely to be exacerbated by the projected substantial increases in population, in particular in the lower Mekong Basin (from 55 to 90 million by 2025, MRC 2003). Furthermore, the precipitation elasticity of Mekong river flow has been estimated as generally greater than zero, meaning that changes in precipitation result in proportionately greater changes in river flow (Hapuarachchi et al., 2008).

Previous studies of the hydrological impacts of potential climate change on the Mekong have generally focussed on climate forcings from individual GCMs or the mean climate change from an ensemble of GCMs. For example, Kiem et al. (2008) used output from the Japanese Meteorological Agency GCM for the IPCC SRES A1b scenario and a gridded hydrological model to show that the mean annual number of wet days, precipitation and discharge would increase by $5.2,6.3$ and $11.7 \%$, respectively between 1979 1988 and 2080-2099. Ishidaira et al. (2008) employed a distributed hydrological model and the mean of the Tyndall Centre v2.03 scenario set. Their results suggested increases in future Mekong discharges up to 2080 with the maximum increases occurring in the middle of the 21 st century.
Whilst useful and informative, previous studies of climate change impacts on Mekong river flow have generally been limited by their adoption of future climate projections from a single GCM or by masking the variation between GCMs through the use of ensemble means. Although GCM simulated temperature can be relatively consistent between GCMs, the same is not true for precipitation. Indeed, projections of future precipitation from different GCMs often disagree even in the direction of change (Randall et al., 2007). For this reason, it is essential that climate change impact studies consider an ensemble of GCMs without resorting to ensemble mean climate change. As part of the wider QUEST-GSI project (Todd et al., 2011; http://www. met.reading.ac.uk/research/quest-gsi/, accessed April 2011), this study addresses the important issue of GCM uncertainty by driving a hydrological model of the Mekong River Basin with outputs from seven different CMIP-3 GCMs (CCCMA CGCM31, CSIRO Mk30, IPSL CM4, MPI ECHAM5, NCAR CCSM30, UKMO HadCM3, UKMO HadGEM1). These GCMs are driven by the policy relevant scenario of a $2{ }^{\circ} \mathrm{C}$ rise in global mean temperature, a presumed threshold of "dangerous" climate change (Todd et al., 2011). In addition, the hydrological impacts of a progressive change in global mean temperature (from 0.5 to $6^{\circ} \mathrm{C}$ ) using one GCM, UKMO HadCM3, are also investigated.

\section{The Mekong River Basin}

The Mekong River is the world's eighth largest in discharge (annual discharge: $475 \mathrm{~km}^{3}$ ), 12th largest in length $(4350 \mathrm{~km})$, and $21 \mathrm{st}$ largest in drainage area $\left(795000 \mathrm{~km}^{2}\right)$. It is a major trans-boundary river, originating at over $5100 \mathrm{~m}$ above sea level in the Tibetan Highlands. The Mekong subsequently flows through the narrow, steep, and in places virtually unexplored Lancang Gorge in China's Yunnan Province before passing through Burma, Laos, Thailand and Cambodia and discharging into the South China Sea from the many distributaries within its delta which lies predominantly within Vietnam (Fig. 1).

The Mekong is initially fed by melting snow in the Tibetan Highlands, where the predominant land cover consists of tundra and montane semi-desert. Although snow covers only approximately $5 \%$ of the Mekong Basin during NovemberMarch (and is negligible at other times), snow storage and subsequent melt has a substantial impact on Mekong runoff (Kiem et al., 2005). Indeed, $27 \%$ of mean annual discharge at Pakse (the terminus of the Mekong 2 sub-basin; see Fig. 1 for location of sub-basins) originates from the uppermost sub-basin (Lancang). The lower Lancang, Nam Ou, Nam Ngum and upper Mekong 1 sub-basins are dominated by forest (both deciduous and evergreen). The Mekong 1 sub-basin is the largest contributor to annual Pakse discharge (39\%). Agriculture forms the greatest land-use type 
in the lower Mekong Basin, particularly in the Chi and Mun sub-basins (which together contribute approximately $10 \%$ of Pakse mean annual discharge) and within the delta.

The vast majority of the basin experiences a monsoonal climate, with seasonal precipitation the primary source of river runoff. The wet season lasts from mid-May to October, and accounts for over $90 \%$ of annual precipitation in many areas. Overall, total annual precipitation ranges from highs of $3200 \mathrm{~mm}$ in parts of Laos, to under $1000 \mathrm{~mm}$ on the comparatively drier Korat plateau in eastern Thailand (i.e. the Chi and Mun sub-basins). Peak river flow at the head of the delta (Phnom Penh) usually occurs in September or October, with the high flow season extending from June to November. Annual minimum flows occur in March or April.

\section{Data and methods}

\subsection{Data}

Baseline climate data for the hydrological model of the Mekong River Basin comprising monthly minimum and maximum temperature, precipitation totals and number of wet days were initially obtained from the $0.5^{\circ} \times 0.5^{\circ}$ gridded CRU TS 3.0 dataset (Mitchell and Jones, 2005), as described in Todd et al. (2011). Monthly data for the 268 grid cells which cover the river basin were stochastically disaggregated to daily resolution following the procedures developed by Arnell (2003) and further described by Todd et al. (2011). Station-based daily precipitation and temperature data (used to define the coefficient of variation for disaggregated daily precipitation data and standard deviation of daily temperature data) were obtained from the US National Climate Data Centre (NCDC) global surface summary of the day (GSOD) meteorological stations used to drive the Kite (2001) Mekong hydrological model. As acknowledged by Kite (2001), the availability of station meteorological data in the Mekong Basin is far from ideal, with a total of 17 stations available for the entire 1961-1990 period, most of which are located in China and Thailand.

Future (monthly resolution) climate scenarios for temperature and precipitation were generated using the ClimGen pattern-scaling technique developed by Arnell and Osborn (2006), and later downscaled to daily resolution following the procedure outlined above. ClimGen is a spatial scenario generator (e.g. Hulme et al., 2000), based on the assumption that the spatial pattern of climate change, expressed as change per unit of global mean temperature change, is relatively constant for a given GCM (Arnell and Osborn, 2006). This allows the pattern of climate change from an individual GCM to be scaled up- and downwards in magnitude, enabling specific (and policy relevant) thresholds of global climate change to be explored (Todd et al., 2011). A further assumption of pattern-scaling (as applied here) is that there is a linear relationship between the global mean temperature and

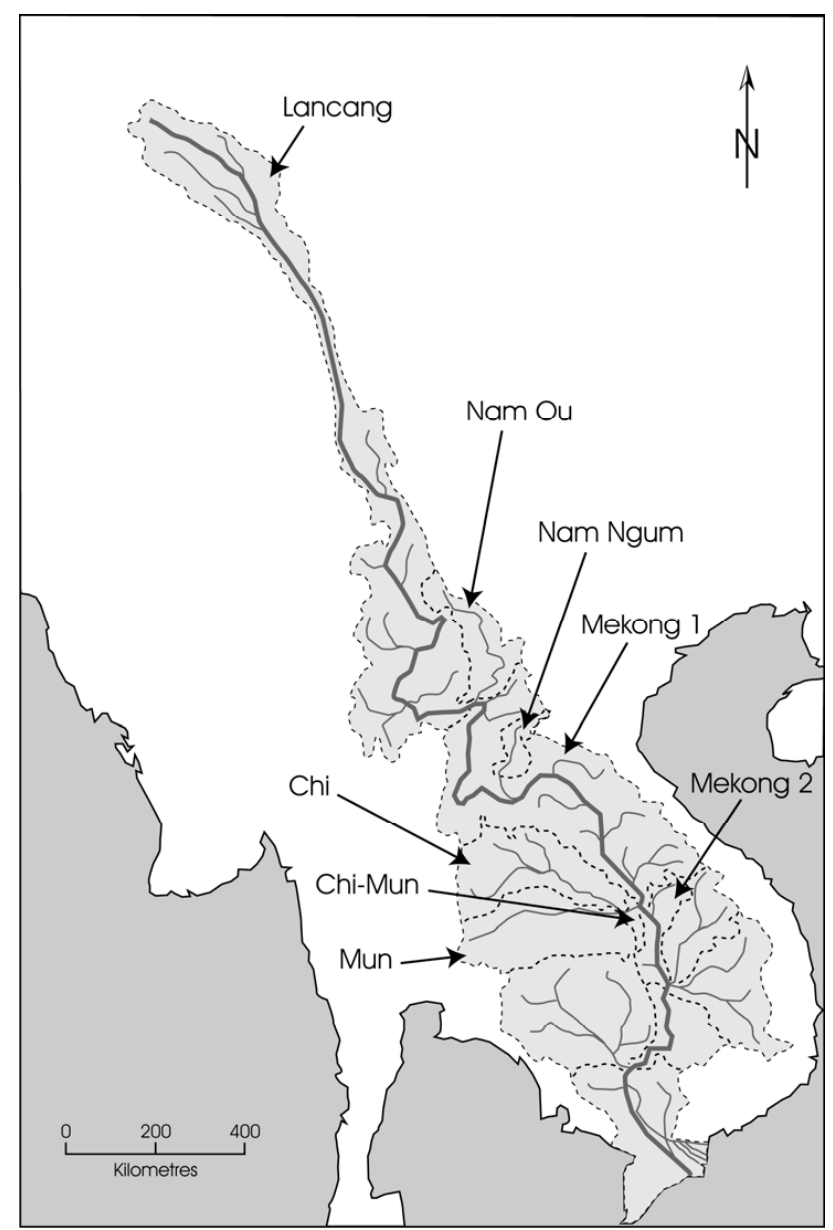

Fig. 1. The Mekong River Basin and sub-basins defined by Kite (2001). Note: only the sub-basins modelled in the current study are labelled.

the response pattern (i.e. grid cell temperature and precipitation). A global-scale validation of the pattern-scaling scenarios indicates that the assumption of linearity is generally satisfactory, but may not hold for large changes in global mean temperature, or where the rate of temperature change slows or even reverses. However, errors associated with patternscaling are generally considered small in comparison to other uncertainties associated with the generation of future climate scenarios (Mitchell, 2003; Warren et al., 2008).

Scenarios were generated here for a prescribed warming of global mean temperature of $0.5,1,1.5,2,2.5,3,4,5$, and $6{ }^{\circ} \mathrm{C}$ using the UKMO HadCM $3 \mathrm{GCM}$, and for a $2{ }^{\circ} \mathrm{C}$ warming using six additional GCMs: CCCMA CGCM 31 , CSIRO Mk30, IPSL CM4, MPI ECHAM5, NCAR CCSM30 and UKMO HadGEM1. Although all GCMs contain certain similarities, by examining climate projections from a number of different models it will nevertheless be possible to draw (implicit) conclusions on the influence of GCM structure on uncertainty in climate change impacts. The subset of 
CMIP-3 GCMs used here was chosen following the analyses described by Todd et al. (2011) to span a range of "plausible" different modelled global climate futures (e.g. Indian monsoon weakening/strengthening, magnitude of Amazon dieback). HadCM3 was chosen as the model for detailed investigation of the impacts of prescribed changes in global mean temperature as it is both a widely used GCM and one that has already undergone considerable analyses of model uncertainty (e.g. Murphy et al., 2004).

\subsection{The SLURP hydrological model}

The hydrological model used to investigate climate change impacts on the Mekong River Basin was the Semi-distributed Land Use-based Runoff Processes (SLURP, v.12.7) model (Kite, 1995). This is a physically based semi-distributed hydrological model that operates on a daily time step. SLURP is described in detail by Kite (2001) so only a brief summary of the model is provided here. The basin is divided into sub-basins according to topography, and each sub-basin is divided into different land cover types. Each land cover type has a unique set of parameters associated with the vertical transfer of water through fast- and slow-responding soil reservoirs. Spatial averages of each climate variable are created for each sub-basin, which are then used to drive the model. Precipitation falls as snow when temperatures are below $0{ }^{\circ} \mathrm{C}$ with snow being stored on the ground surface. Accumulated snowmelt is computed on a daily basis using a degree-day method (Rango and Martinec, 1995), including the cold content of the snowpack (St. Laurent, 2003).

The SLURP model has been successfully employed in a range of different environments. These range from small Canadian wetland basins of less than $1 \mathrm{~km}^{2}(\mathrm{Su}, 2000)$, through catchments of hundreds of square kilometres with very different climatologies including studies in Canada (Armstrong and Martz, 2008), Germany (Viney et al., 2009), Turkey (Apaydin et al., 2006) and South Korea (Kim et al., 2007; Park et al., 2009), to major river basins including upper tributaries of the Indus and Yangtze (Jain et al., 1998; Woo et al., 2009).

The Mekong River Basin has previously been modelled using SLURP, for the period 1994-1998 (Kite, 2001). In this previous study, the basin was divided into 13 subbasins (Fig. 1) based on the United States Geological Survey (USGS) GTOPO-30 digital elevation model. Land cover types within each sub-basin were derived from the USGS $1 \mathrm{~km}$ digital land cover map of the world, with soil parameters generated using data from the FAO World Soil Map (FAO, 1990). As stated previously, the climate data used to drive the original Mekong SLURP model consisted of station-based daily meteorological data from the NCDC GSOD dataset. The whole 1994-1998 period was employed as the simulation period without calibration and daily river flow was shown to be simulated "reasonably well" at a number of gauging stations (Kite, 2001).
The present study started with the same SLURP model, topographic, land cover and soil data, sub-basins and model parameters used by Kite (2001), but with the model run for the much longer 1961-1998 period. It is acknowledged that the use of temporally constant land-cover types for the analysis period is a potential source of error. Previous research has shown that rainfall-runoff relationships have varied over recent decades for sections of the Mekong upstream of Pakse, with this variation thought to be a response to changing landcover types (Lacombe et al., 2010). However, in the absence of a long-term land cover dataset the land cover data successfully used by Kite (2001) was retained. In common with other modelling studies undertaken within the QUESTGSI project (e.g. Hughes et al., 2011; Kingston and Taylor, 2010), a baseline period of 1961-1990 was used for calibration, with the remaining 1991-1998 data used for validation. The input climate data were derived from the monthly CRU TS 3.0 dataset disaggregated to daily resolution (as described in Todd et al., 2011), rather than the relatively sparse GSOD daily station based dataset. Although SLURP operates on a daily time-step, results are only considered at a monthly resolution due to the use of a stochastic weather generator to generate daily climate data. As with the Kite (2001) study, the Mekong Basin was only modelled as far as the Pakse gauging station in Laos (i.e. the terminus of the "Mekong 2 " sub-basin) which is upstream of the many distributaries of the river's extensive delta. The modelled area was therefore $550000 \mathrm{~km}^{2}$ rather than the total $795000 \mathrm{~km}^{2}$ of the whole Mekong Basin.

\subsection{Calibration and validation of the SLURP hydrological model}

Data from three gauging stations were available for calibration of the SLURP hydrological model: Chiang-Saen (the terminus of the Lancang sub-basin, with an upstream area of $228000 \mathrm{~km}^{2}$ ), Ubon (the Chi, Mun and Chi-Mun sub-basins, $122390 \mathrm{~km}^{2}$ ), and Pakse (the entire modelled area, i.e. the terminus of the Mekong 2 sub-basin). Model calibration was undertaken sequentially from upstream to downstream (i.e. Chiang-Saen and Ubon before Pakse), and was particularly focussed on the Chiang-Saen and Pakse stations as the combined Chi, Mun and Chi-mun sub-basins (i.e. Ubon gauging station) contribute only $10 \%$ of the mean annual flow at Pakse (in comparison to $27 \%$ from Lancang).

Initial runs of the SLURP model for the 1961-1990 calibration period indicated that it would be necessary to modify existing values of model parameters in order to gain a satisfactory fit between modelled and observed discharge. Modelled discharge using the original (Kite, 2001) parameter values was too high in all months whilst the transition to and from the high flow season was too gradual. The need for re-calibration was expected given the different time period for which the model was being run and the different climate data being used. This is in common with previous 
Table 1. Nash Sutcliffe (NS) values and percent difference between modelled and observed (modelled minus observed) for the three calibration points in the Mekong Basin during the calibration $(C)$ and validation $(V)$ periods. (Validation period values for Ubon are not given as data for Ubon ends in 1993.)

\begin{tabular}{|c|c|c|c|c|c|c|c|c|}
\hline \multirow[t]{2}{*}{ Gauge } & \multicolumn{2}{|c|}{ NS } & \multicolumn{2}{|c|}{ Annual mean } & \multicolumn{2}{|c|}{$\begin{array}{c}\text { Month of peak } \\
\text { flow }\end{array}$} & \multicolumn{2}{|c|}{$\begin{array}{c}\text { Month of } \\
\text { minimum flow }\end{array}$} \\
\hline & $C$ & V & $C$ & V & $C$ & V & C & $V$ \\
\hline Pakse & 0.89 & 0.77 & +0.9 & -4.2 & $-10.0 \%$ & $-20.4 \%$ & $-22.2 \%$ & $-4.8 \%$ \\
\hline Chiang-Saen & 0.78 & 0.81 & $+8.2 \%$ & $+2.4 \%$ & $-1.3 \%$ & $+10.3 \%$ & $-10.4 \%$ & $-24.3 \%$ \\
\hline Ubon & 0.44 & & $+41.9 \%$ & & $+5.1 \%$ & & $+5.8 \%$ & \\
\hline
\end{tabular}

research that has shown that hydrological models may require recalibration when meteorological inputs are changed from station-based records to gridded datasets (Mileham et al., 2008; Xu et al., 2010).

The calibration of the Mekong model was determined by the SLURP model structure and was based on modifications to parameters which vary between land cover types (i.e. transport of water through the soil profile: the retention constants and capacities of the fast and slow soil stores) and those which vary between sub-basins (evaporation, Manning's roughness and field capacity coefficients). Initial minor manual adjustment of SLURP parameters proved ineffective, with the model continuing to simulate monthly discharges which were substantially higher than those of the observed records at the three gauging stations, particularly during the rising and descending limbs of the annual flood peak. The Shuffled Complex Evolution method of model autocalibration developed at the University of Arizona (SCE-UA) is embedded within SLURP, but application of this method failed to improve the model calibration. This is thought to be because autocalibration within SLURP can only be performed at a daily time-step, and the disconnect between daily temperature, precipitation and discharge introduced by artificially generating daily weather data prevents the autocalibration routine from working effectively at this temporal resolution.

Following these initial calibration attempts, more substantial changes were made to the model. The potential evapotranspiration (PET) routine was changed from the original Penman-Monteith method to the less data-intensive and more empirical temperature-based Linacre method. Although this resulted in substantial improvements, including lower modelled discharge and a better match to the shape of the observed annual hydrograph, results were still considered to be beyond the bounds of acceptability.

Improvement in model performance following the adoption of a less data-intensive PET method suggests that data quality may be an issue. There are two principal reasons why this may be the case. Firstly, Penman-Monteith PET requires humidity, wind speed and net radiation data in addition to temperature. The former variables are typically less reliable in gridded datasets, due in part to measurement difficulties and a relatively limited number of data points, particularly for the latter two variables (e.g. New et al., 1999). The second factor is more specific to the upper section of the Mekong River Basin (i.e. the Lancang sub-catchment), where the river passes through a series of very narrow gorges. In places, these gorges are substantially narrower than the $0.5^{\circ}$ resolution of the input climate data. Coupled with the likely high spatial variability of local climate over this complex terrain and the relatively poor coverage of station data used to construct the gridded CRU data for this region, the representivity of gridded datasets is liable to be poor in the upper Mekong Basin. This is likely to be particularly important for precipitation, which can exhibit high spatial variability even over relatively homogeneous terrain. In light of the potential poor representivity of the CRU precipitation data, an alternative precipitation dataset, the University of Delaware global precipitation dataset (UDel) based on Legates and Wilmott (1990), was used to investigate whether poor model performance was due, in part, to the precipitation data used to drive the model.

Initial results using the UDel precipitation dataset produced a marked improvement in model performance compared to those based on the original CRU TS 3.0 data. Although this is initially surprising (the CRU database contains more station data points than UDel), these results follow previous findings (Hughes et al., 2011). One possible reason for this apparent contradiction is that whilst the CRU dataset intermittently captures more detail in regional precipitation than UDel, not all of this regional detail is relevant for the Mekong River Basin (i.e. occurs beyond the basin boundary).

Further manual adjustment of model parameters was undertaken following the guidelines provided by Kite (2008). UDel-driven simulation of Pakse mean monthly discharge (with Linacre-derived PET) was bought substantially closer to the observed values (Table 1, Fig. 2a). However, discharge was still slightly underestimated during the peak and low flow seasons, and slightly overestimated during the transition months. It was not possible using reasonable parameter adjustment to further increase modelled river flow during the high and low flow seasons without also increasing the overestimation of flow during the transition seasons. The ascending limb and seasonal peak of the Chiang-Saen annual 

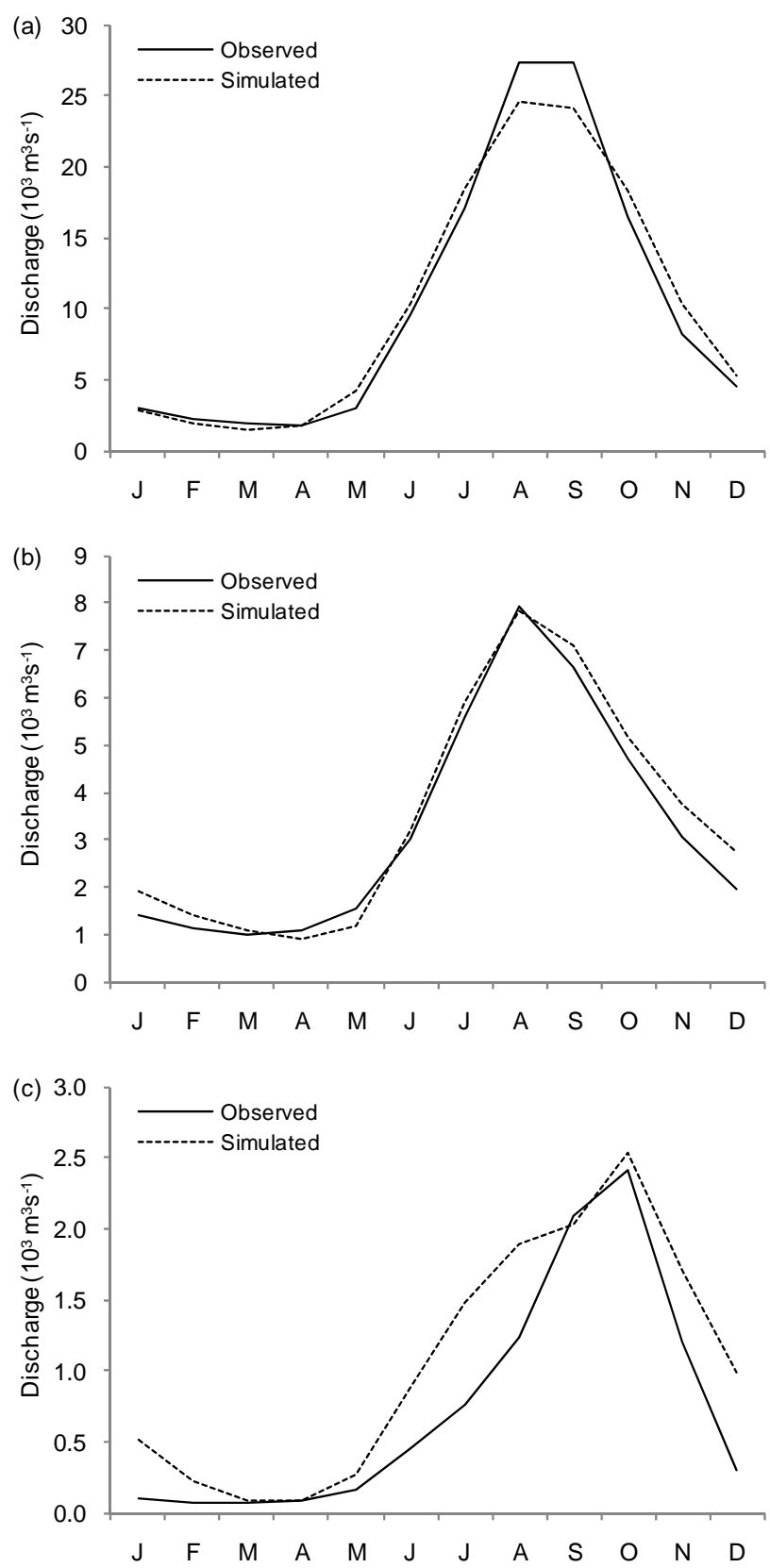

Fig. 2. Observed and simulated mean monthly discharges (19611990): (a) Mekong at Pakse (Mekong 2), (b) Lancang sub-basin at Chiang-Saen, (c) Chi-Mun sub-basin at Ubon (note varying y-axis scales).

hydrograph are well captured, but with some overestimation of the descending limb, leading to modelled annual minimum flow occurring a month later than observed (i.e. April as opposed to March; Table 1, Fig. 2b). Although peak and low season discharges were successfully captured for Ubon, as at Pakse rising and descending limb discharges were generally too high (Table 1, Fig. 2c).
The Nash-Sutcliffe coefficients (NS) for monthly discharge for the 1961-1990 calibration period are 0.89 (Pakse), 0.78 (Chiang-Saen) and 0.44 (Ubon) (Table 1). According to the classification scheme of Henriksen et al. (2008) the NS value for Pakse is "excellent" and that for Chiang-Saen "very good". The relatively low value for Ubon (classified as "poor") is likely to reflect the aforementioned discrepancies in the simulation of the rising and descending limbs of the annual hydrograph. Although difficult to make precise comparisons with previous studies (due to the use of different performance metrics and different study periods), the SLURP model used herein appears to be at least as good as previous attempts at modelling the Mekong. For example, observed-modelled differences in mean monthly flow in the study of Kite (2001) vary between +14 and $-37 \%$; NS values for different sub-basins in the study of Hapuarachchi et al. (2008) vary between 0.7 and 0.83 ; an NS value of 0.63 was achieved for Kratie (downstream of Pakse) discharge by Västilä et al. (2010).

The performance of the model does not vary greatly between the calibration and validation periods at Pakse (Table 1). Similarly, little change in the correspondence between model results and observations occurs for Chiang-Saen (Table 1). Statistical validation of modelled Ubon river flow was not undertaken because observed data is only available for this gauge up to 1993; however visual analysis of the data (not shown) indicates few major departures from the observed-modelled relationship obtained for the calibration period.

The implications of the disaggregation of monthly data to a daily time-step were investigated by running the disaggregation procedure ten times to determine the sensitivity of the hydrological model to the random sequencing of rainfall events within each month. The Nash-Sutcliffe coefficient for Pakse varied by less than 0.05 between the original run and the mean of the ten subsequent runs. Very similar 30-yr monthly mean flows were obtained suggesting that the model is not very sensitive to the disaggregation procedure.

\section{Scenario results: prescribed warming using HadCM3}

\subsection{Changes in climate}

Changes in temperature associated with prescribed warming of global mean temperature using the HadCM3 GCM are relatively uniform across the seven modelled sub-basins of the Mekong, with only the Lancang sub-basin experiencing slightly different changes. Temperatures increase linearly with increasing global mean temperature. The greatest warming in all sub-basins occurs from November-April (e.g. 2.5 to $3.5^{\circ} \mathrm{C}$ in the $2{ }^{\circ} \mathrm{C}$ scenario), with slightly weaker warming occurring in the May-October period (e.g. 2.0 to $2.5^{\circ} \mathrm{C}$ for the $2{ }^{\circ} \mathrm{C}$ scenario). The Lancang sub-basin has 
Table 2. Percent change in Pakse (Mekong 2) annual mean, Q5 and Q95 discharges for $0.5-6^{\circ} \mathrm{C}$ increases in global mean temperature using HadCM3.

\begin{tabular}{llll}
\hline Scenario & Q5 & Mean & Q95 \\
\hline $0.5^{\circ} \mathrm{C}$ & -7.7 & -3.7 & 2.8 \\
$1.0^{\circ} \mathrm{C}$ & -3.6 & -0.7 & -0.6 \\
$1.5^{\circ} \mathrm{C}$ & -8.6 & -4.7 & 3.2 \\
$2.0^{\circ} \mathrm{C}$ & -7.6 & -1.6 & 0.4 \\
$2.5^{\circ} \mathrm{C}$ & -11.3 & -5.4 & 10.4 \\
$3.0^{\circ} \mathrm{C}$ & -11.3 & -2.6 & 8.9 \\
$4.0^{\circ} \mathrm{C}$ & -4.4 & 4.5 & 24.0 \\
$5.0^{\circ} \mathrm{C}$ & -9.9 & -2.0 & 26.2 \\
$6.0^{\circ} \mathrm{C}$ & -11.4 & -0.2 & 26.7 \\
\hline
\end{tabular}

slightly more consistent year-round warming but a similar overall magnitude of increasing temperatures. Inter-seasonal and inter-basin patterns are the same for all scenarios, but with increasing magnitude from the 0.5 to the $6{ }^{\circ} \mathrm{C}$ scenario, such that for the $6^{\circ} \mathrm{C}$ scenario warming is between 7.5 and $10.5^{\circ} \mathrm{C}$ for November-April and 6.0 and $7.5^{\circ} \mathrm{C}$ for MayOctober.

On an annual basis, the HadCM3 precipitation climate change signal (relative to the UDel baseline) is $\leq 1 \%$ for all except the three most northerly sub-basins, all of which show increases (for the $2{ }^{\circ} \mathrm{C}$ scenario, Lancang: $10 \%$; Nam Ou: $11 \%$; Nam Ngum: $5 \%$ ). In contrast, the monthly precipitation signal is highly variable, albeit with linear rates of change with increasing global mean temperature. The two most northerly sub-basins, Lancang and Nam Ou, show increasing precipitation for nearly all months; April is the only month that has notable decreases (up to $16 \%$ decrease for the $2{ }^{\circ} \mathrm{C}$ scenario, $40 \%$ for the $6^{\circ} \mathrm{C}$ scenario). Increases of approximately $20 \%$ for the $2{ }^{\circ} \mathrm{C}$ scenario $(60 \%$ for the $6{ }^{\circ} \mathrm{C}$ scenario) occur for both sub-basins in February, May, September and October. The remaining sub-basins have a more variable intra-annual signal, with decreases from October-April (by up to $50 \%$ for $2^{\circ} \mathrm{C} ; 70 \%$ for $6{ }^{\circ} \mathrm{C}$ ) and July-August (up to $8 \%$ for $2{ }^{\circ} \mathrm{C} ; 20 \%$ for $6^{\circ} \mathrm{C}$ ), and increases from May-June (up to $17 \%$ for $2{ }^{\circ} \mathrm{C} ; 60 \%$ for $6^{\circ} \mathrm{C}$ ).

\subsection{Changes in river flow}

Results from the scenarios of prescribed increases in global mean temperature from 0.5 to $6^{\circ} \mathrm{C}$ using the $\mathrm{HadCM} 3 \mathrm{GCM}$ generally show small decreases in annual runoff at Pakse (Table 2). Unlike the changes in temperature and precipitation, modifications in river flow do not occur linearly with increasing global mean temperature for either the mean discharge or the Q5 and Q95 flows (i.e. the discharges exceeded $5 \%$ and $95 \%$ of the time, respectively). Furthermore, high and low flows change in different directions, with low flows generally increasing, and high flows generally decreasing (Table 2).
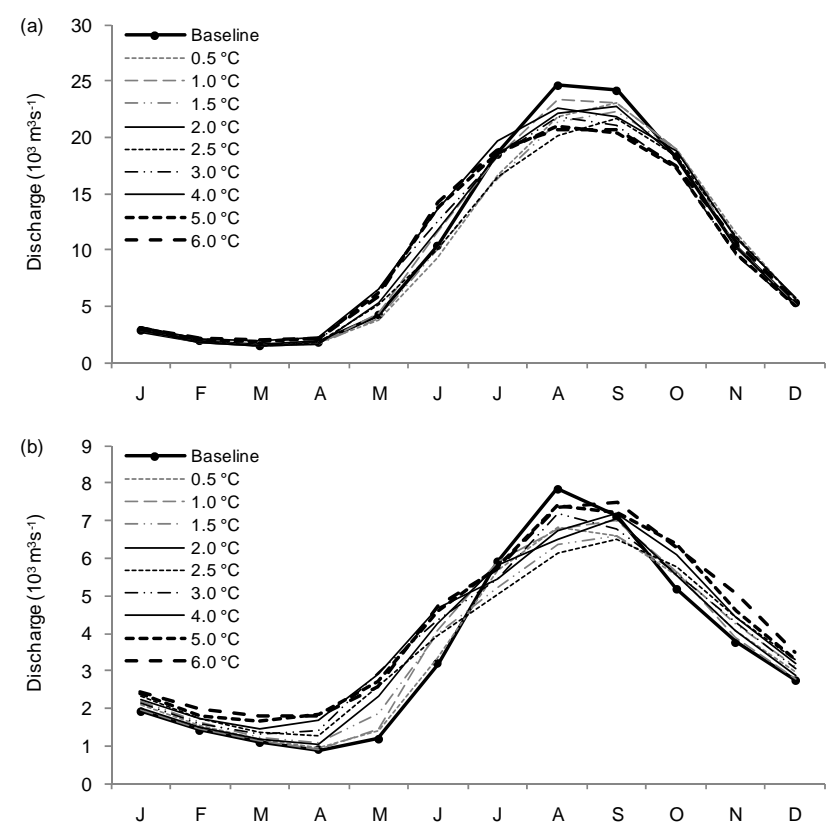

Fig. 3. HadCM 3 climate change signal for $0.5-6{ }^{\circ} \mathrm{C}$ increases in global mean temperature: (a) mean monthly discharge of the Mekong at Pakse (Mekong 2), (b) mean monthly discharge of the Lancang sub-basin at Chiang-Saen.

Reductions from the Pakse baseline mean annual flow vary between 0.2 and $5.4 \%$, but with little apparent link to the magnitude of global temperature change; the smallest annual change occurs in the $6^{\circ} \mathrm{C}$ scenario whereas the largest arises in the $1.5^{\circ} \mathrm{C}$ scenario. The $4{ }^{\circ} \mathrm{C}$ scenario is somewhat of an outlier with a $4.5 \%$ increase in mean annual runoff from the 1961-1990 baseline.

Whilst relatively small changes in the annual mean runoff at Pakse are projected under increases in global mean temperature, more substantial changes occur at Q5 and Q95, reaching $-11.4 \%$ and $+26.7 \%$ respectively (Table 1 ). Large changes also occur in monthly discharge (Fig. 3a). River flow during August and September (the months of annual peak flow) decreases on average by 0.2 and $9.8 \%$ (respectively) for the $2{ }^{\circ} \mathrm{C}$ scenario, with changes of $+2.4 \%$ and $-16.0 \%$ for the $6^{\circ} \mathrm{C}$ scenario. Although discharge decreases in most months, the largest monthly changes involve increases and occur in June $\left(+27.0 \%\right.$ for $2{ }^{\circ} \mathrm{C} ;+55.6 \%$ for $4{ }^{\circ} \mathrm{C}$, and $+40.1 \%$ for the $6^{\circ} \mathrm{C}$ scenario). These contrasting trends occur because whilst temperature increases for all sub-basins in all months of the year, changes in precipitation vary in direction (both between sub-basins and months). The interaction of these contrasting climatic trends and their impacts on monthly river flow provides partial explanation for the absence of a progressive linear trend in annual runoff as global mean temperature increases. 

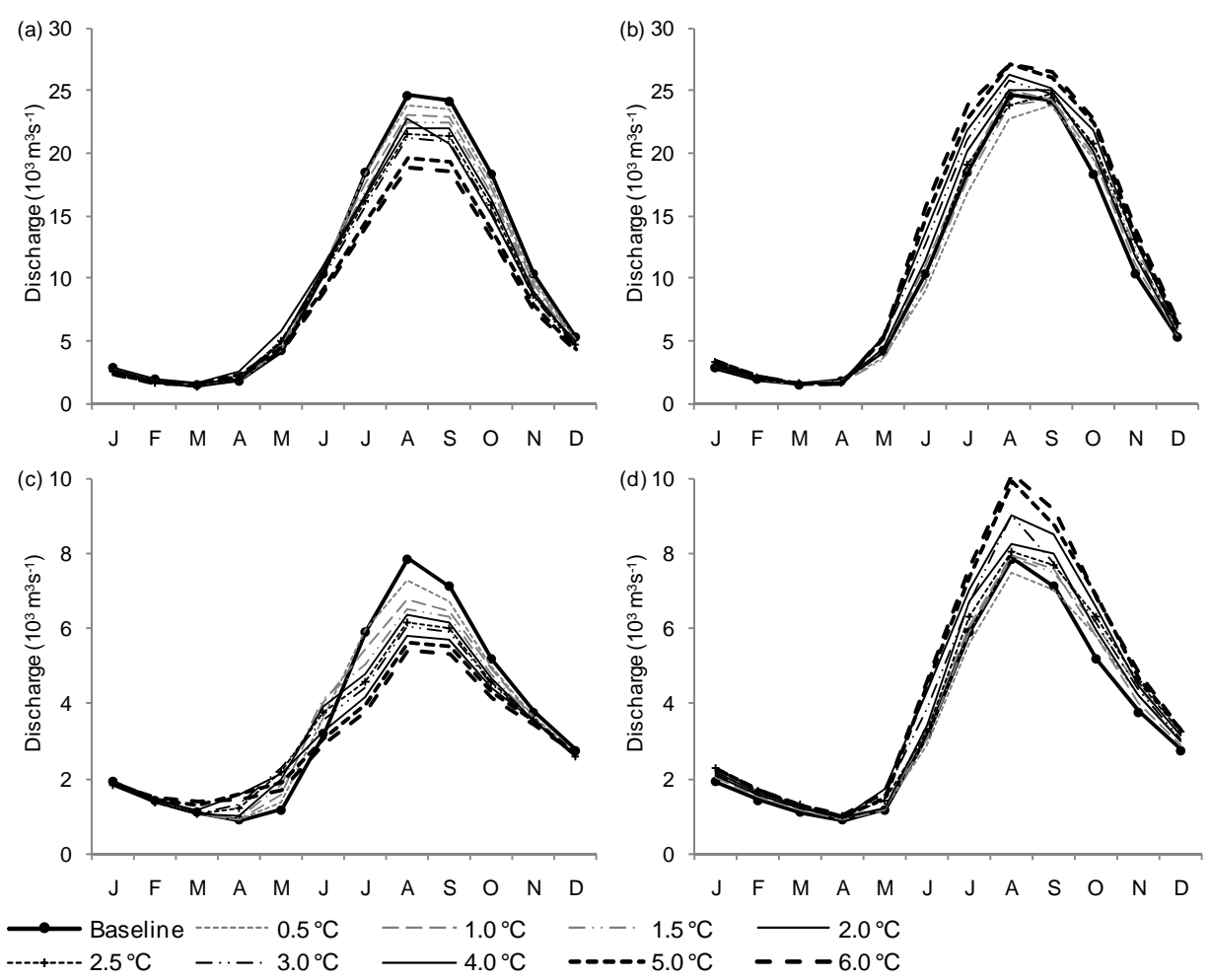

Fig. 4. HadCM3 climate change signal for $0.5-6{ }^{\circ} \mathrm{C}$ increases in global mean temperature for the Mekong at Pakse (Mekong 2): (a) temperature only, (b) precipitation only; and Lancang at Chiang-Saen: (c) temperature only, (d) precipitation only.

Further explanation for the absence of a progressive linear trend in annual runoff can be provided by considering the role of temperature, and specifically the balance between snow storage and release in the upper Mekong Basin and increasing PET throughout the basin. In contrast to the overall Mekong response, the Lancang sub-basin (Chiang-Saen gauging station) shows a near-linear increase in annual runoff from the $0.5(+1.4 \%)$ to $6^{\circ} \mathrm{C}(+15.3 \%)$ scenarios. Increasing annual runoff in the Lancang sub-basin is driven by increasing early and late season discharge, although counterbalanced by decreasing peak season discharge (Fig. 3b). As increases in precipitation occur in all months (Sect. 4.1), the early season increases at Lancang are thought to be primarily a result of higher temperatures and, in turn, enhanced snowmelt earlier in the year. This is demonstrated by the division of the river flow climate change signal into that attributable to temperature and precipitation (by holding temperature constant and varying precipitation, and vice versa) (Fig. 4). This shows that with increasing temperature and unchanged precipitation, early season river flow increases, indicating the role of enhanced snowmelt and/or an increasing rain-to-snow ratio. Similarly, with stable temperature and changing precipitation year-round increases in river flow are observed.

Increasing river flow in the Lancang sub-basin is likely to be at least partly responsible for the non-linear response of Pakse river flow to increasing global mean temperatures (seen also in the Pakse temperature only climate change signal: Fig. 4a). The peak in the combined Pakse $4{ }^{\circ} \mathrm{C}$ scenario is therefore thought to be the result of the combination of increasing Lancang discharge (from the higher rain:snow ratio and greater snowmelt) and seasonal changes in precipitation across the Mekong Basin against the counterbalance of increasing PET throughout the basin.

\section{Scenario results: $2^{\circ} \mathrm{C}$ warming across seven GCMs}

\subsection{Changes in climate}

The $2{ }^{\circ} \mathrm{C}$ prescribed warming scenarios from the seven different GCMs show contrasting changes in climate over the Mekong Basin. For temperature, all GCMs show increases of close to $2{ }^{\circ} \mathrm{C}$, but with variation between GCMs in the monthly patterns of rising temperatures. For example, the CCCMA, HadGEM1 and NCAR GCMs show a relatively constant temperature climate change signal throughout the year for most sub-basins; the CSIRO and MPI GCMs have a distinct peak in April; HadCM3 peaks in February and the IPSL GCM has a broad peak in temperature rise from March-June. Also of note is the difference in the temperature signal over the Lancang sub-basin compared to the other sub-basins. For all GCMs except HadCM3 the temperature 
Table 3. Percent change in Pakse (Mekong 2) annual mean, Q5 and Q95 discharges for $2{ }^{\circ} \mathrm{C}$ increase in global mean temperature using seven GCMs.

\begin{tabular}{llll}
\hline GCM & Q5 & Mean & Q95 \\
\hline CCCMA & 1.8 & 5.7 & 8.0 \\
CSIRO & -18.0 & -17.8 & -13.4 \\
HadCM3 & -7.6 & -1.6 & 0.4 \\
HadGEM1 & -18.1 & 6.5 & -1.9 \\
IPSL & -5.1 & -10.2 & -16.2 \\
MPI & 5.9 & -9.5 & -3.0 \\
NCAR & 6.3 & 3.0 & 5.9 \\
\hline
\end{tabular}

increase in the Lancang sub-basin is much greater than for the other sub-basins between January and April (for HadCM3 the Lancang temperature signal is instead weaker than for other sub-basins during these four months).

Differences in the precipitation climate change signal between GCMs are far greater than for temperature, with little consistency in the magnitude, direction or seasonality of change, or the level of similarity between sub-basins. At the annual level for the entire Mekong Basin, the CCCMA, HadCM3, MPI and NCAR GCMs show increasing precipitation (by $3-10 \%$ ) whereas the CSIRO, HadGEM1 and IPSL GCMs show decreases in precipitation of 3,2 and $1 \%$, respectively. Increasing annual precipitation occurs across all sub-basins for the CCCMA, MPI and NCAR GCMs, with decreases across all sub-basins shown by the CSIRO GCM. For the other GCMs, the increase in annual precipitation for the northerly sub-basins in the HadCM3 scenarios was noted in Sect. 4.1. HadGEM1 also shows increases of $6 \%$ and $1 \%$ for the Lancang and Nam Ousub-basins, respectively, but decreasing annual precipitation for the other sub-basins (peaking at $5 \%$ in the Chi and Munsub-basins). In contrast to the two Hadley Centre GCMs, IPSL shows decreasing precipitation for the three northerly sub-basins, peaking at $5 \%$ for Lancang and Nam Ou, together with small $(<1.5 \%)$ increases in Chi-Mun and Mekong 2 precipitation. Interseasonal patterns of change range from unimodal (maximum decreases in January-March and peak increase in September: CSIRO, IPSL) to bimodal (with peak increases around April and September, and decreases in June-July and DecemberJanuary: CCCMA, NCAR, HadCM3, HadGEM1, MPI).

\subsection{Changes in river flow}

Projected changes in Pakse discharge show substantial disparities between GCMs, with little consistency in either the magnitude or direction of change for annual or seasonal mean discharge, or high and low flows (Table 3, Fig. 5a). There is no particular clustering of GCMs so it is not possible to label any GCM as an outlier, especially given that these seven GCMs are drawn from a larger population of 23
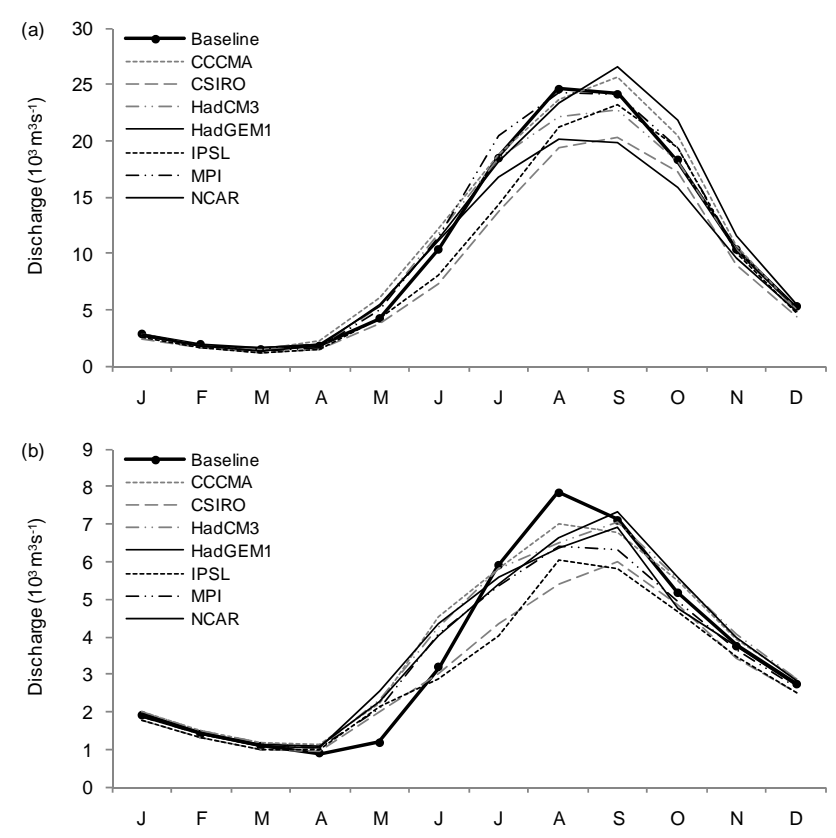

Fig. 5. $2{ }^{\circ} \mathrm{C}$ climate change signal across seven GCMs: (a) mean monthly discharge of the Mekong at Pakse (Mekong 2), (b) mean monthly discharge of the Lancang sub-basin at Chiang-Saen.

CMIP-3 GCMs (Meehl et al., 2007). The same is true for Ubon (Chi-Mun discharge). However, whilst substantial differences between GCMs also occur in the Lancang sub-basin (Chiang-Saen gauging station), results for all seven GCMs show increasing river flow from April-June, and decreasing flow in July and August (Fig. 5b).

Results from running the model with scenario precipitation and baseline temperature (and vice versa) show that it is inter-GCM differences in scenario precipitation that are the primary cause of variation in the overall climate change signal in Mekong (Pakse) discharge (Fig. 6a, b). The temperature-only climate signal in mean monthly discharge is very consistent between all seven GCMs. In contrast, the precipitation-only climate change signal shows both increases and decreases in monthly discharge. Similar results are found for the Lancang sub-basin (Fig. 6c, d), indicating that the April-June rising trend in river flow is a temperature rather than precipitation driven trend. As with the HadCM3 results, these results demonstrate the likely importance of snowmelt and the snow-to-rain ratio of precipitation for Lancang river flow.

\section{Uncertainty in model parameterisation}

In the absence of quantitative estimates of uncertainty associated with model parameterisation from an autocalibration routine, a manual assessment was made to provide an indication of model parameterisation uncertainty. This was 

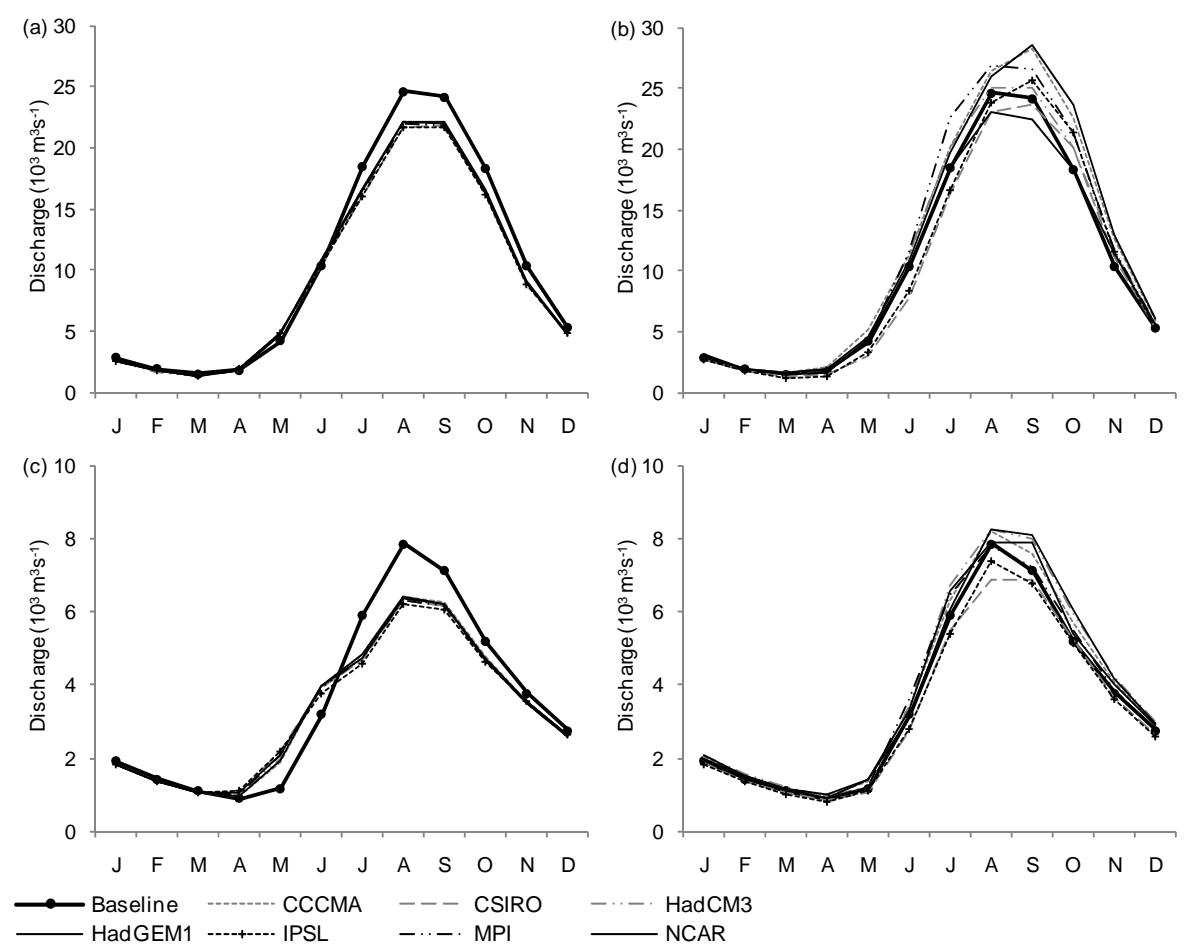

Fig. 6. $2{ }^{\circ} \mathrm{C}$ climate change signal across seven GCMs for the Mekong at Pakse (Mekong 2): (a) temperature only, (b) precipitation only; and Lancang at Chiang-Saen: (c) temperature only, (d) precipitation only.

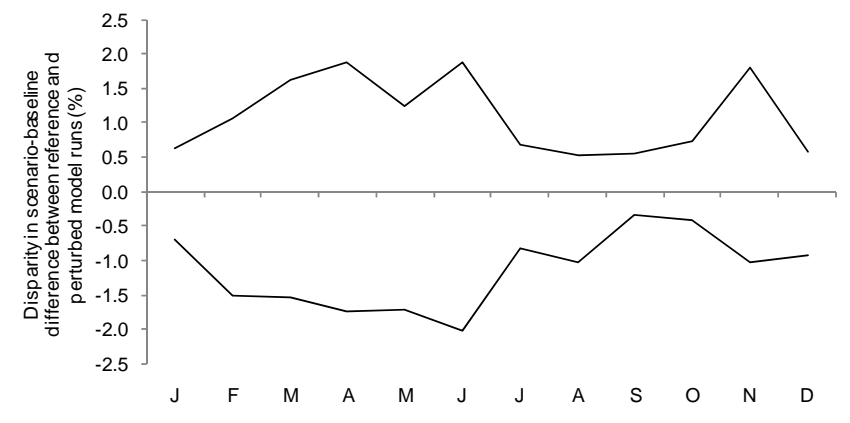

Fig. 7. Model parameter uncertainty for HadCM $32{ }^{\circ} \mathrm{C}$ scenario: maximum extent of the disparity between the scenario-baseline difference in the perturbed parameter versus reference model runs.

undertaken by varying the most sensitive parameters in the hydrological model. Seven parameters were selected based on the results from initial manual model calibration and parameter sensitivity rankings provided by Kite (2008). The parameters investigated were the retention constants and capacities of the fast and slow soil stores, and coefficients for evaporation, field capacity and Manning's roughness.

Each parameter was varied by $+/-10 \%$ from the calibrated value and the model re-run with baseline climate data. The model was then run using the same perturbed parameter set with scenario climate data (the HadCM $32{ }^{\circ} \mathrm{C}$ prescribed warming was used as an exemplar scenario). The difference between the reference and perturbed runs was then compared between baseline and scenario situations. If the difference between the reference and perturbed runs is greater for the scenario than the baseline, then model parameterisation may be a cause of further uncertainty in climate change projections (and vice versa).

Results of the uncertainty analysis indicate that model parameterisation generally imparts little additional uncertainty to the climate change projections relative to that generated by differences in GCM precipitation (Fig. 7). This is in agreement with previous studies (e.g. Prudhomme and Davies, 2009). However, it should be noted that the findings presented here are based on the HadCM $32{ }^{\circ} \mathrm{C}$ prescribed warming scenario only. Differences in the reference-perturbed percent anomaly between baseline and HadCM3 $2{ }^{\circ} \mathrm{C}$ scenario runs are generally less than $+/-2 \%$, with the most sensitive parameters relating to soil water capacity and the Manning's roughness coefficient of the river channel.

\section{Discussion}

This paper has presented an important assessment of future availability of freshwater resources within the Mekong Basin as a result of climate change, combined with an evaluation of the range of uncertainty in this assessment due to climate sensitivity, choice of GCM and hydrological model 
parameterisation. As such, this study provides a useful context to previous analyses of climate change impacts on Mekong river flow based on a single GCM or ensemble means. The overwhelming dependence on the GCM used for projections of future availability of freshwater resources has been demonstrated (following other QUEST-GSI studies; summarised by Todd et al., 2011), which indicates that single-GCM or ensemble mean evaluations of climate change impacts are unlikely to provide a representative depiction of possible future changes in river flow. It is also interesting to revisit the concept of precipitation elasticity of river flow (as calculated for the Mekong by Hapaurachchi et al., 2008) - although a useful statistic, it is of limited use in climate change scenarios, given the strong influence of both precipitation and temperature on future discharge variation.

Despite the substantial uncertainty associated with the choice of GCM, a number of additional important issues are raised by these results which are both specific to the Mekong, and of more general relevance to the assessment of climate change impacts on water resources. For example, results show that the GCM temperature signal for river flow is far more consistent than the precipitation signal (see Kingston and Taylor, 2010). As such, some confidence can be placed in the finding that flows in the upper Mekong Basin will increase in the first half of the calendar year due to enhanced melting of snow and ice since this result is consistent across all GCMs and all scenarios examined. The importance of snow accumulation and melt dynamics has previously been demonstrated for the Mekong Basin (Kiem et al., 2005). Increasing temperature can also be expected to lead to increased evaporation throughout the basin.

The results also demonstrate that when averaged over large areas such as the Mekong or even its sub-basins, neither high, low, nor mean annual river flow may respond in a linear way to increasing temperatures. This nonlinearity concurs with the findings of Ishidaira et al. (2008). The nonlinear changes to Mekong river flow are thought to be a consequence of contrasting response to increased temperature in different parts of the Mekong Basin (earlier snowmelt versus increased evapotranspiration), complicated by seasonally and spatially variable changes in precipitation. Similarly complex responses to projected climate change have also been found in studies of other rivers that also have a strong snowmelt component to annual discharge (e.g. Thorne, 2010).

Two further important issues can also be highlighted: firstly, the potential for thresholds of climate change impacts on water resources (possibly $4^{\circ} \mathrm{C}$ here), and secondly, the importance of investigating changing water resources on an intra-annual basis as it is the combination of different changes in monthly river flow that can lead to a non-linear response at an annual resolution. In large basins that cross climatic zones, such as the Mekong, further complication is added by the possibility of contrasting climate trends and changes in the relative importance of different hydrological processes in different sections of the basin. These factors make it difficult to ascribe simple attributions to downstream trends in discharge.

Results of this study demonstrate the importance of understanding the roles and interaction of changes in temperature and the implications of this for both PET and storage of precipitation as snow or ice. Together with changing magnitudes and seasonality of precipitation, these temperature driven changes have important implications for river flow. This is further complicated by the time taken for water to pass through the continental-scale Mekong River Basin. Although the role of PET is key to changes in the hydrological behaviour of the Mekong, there remains substantial uncertainty regarding estimation of both baseline and scenario PET. Whilst the relative advantages and disadvantages of many different methods of estimating historical PET from meteorological data have been widely considered (e.g. Vorosmarty et al., 1998; Lu et al., 2005), relatively little attention has been given to how representative different PET methods remain when transferred from baseline to scenario climatology. Indeed, recent work (Kingston et al., 2009; Kingston and Taylor, 2010) has shown that different methods of estimating PET can produce markedly different climate change signals, suggesting that this is an area for further research.

Whilst further uncertainty in the climate change signal for the Mekong River Basin is likely to arise from the parameterisation and structure of the hydrological model used, the findings presented here indicate that such uncertainty is much smaller than that associated with choice of GCM, climate sensitivity, and possibly observed baseline data. Despite this, it should be noted that this paper has only conducted an initial (and subjective) assessment of model parameter uncertainty. These findings should therefore be taken as indicative rather than definitive. Future work will aim to treat model uncertainty in a more objective probabilistic manner (for example, by using autocalibration routines). Future work would also benefit from inclusion of scenarios of land cover change.

\section{Conclusions}

This study of climate change impacts on the hydrology of the Mekong River Basin has revealed a number of important findings. Firstly, and most importantly, it has been shown that projections of hydrological change in the basin are highly dependent upon the direction of projected changes in precipitation. The considerable differences in precipitation projections produced by different GCMs emphasise the need for multi-model evaluations of climate change impacts. It is notable that this is still the case even in a region highlighted by the IPCC 4th Assessment Report as having a relatively consistent precipitation climate change signal.

Despite such uncertainty, it has been demonstrated that useful information can still be obtained, for example by focussing on future changes in discharge associated with 
changing temperature, as temperature is consistently simulated to rise across the Mekong River Basin by all seven GCMs. Accordingly, this study has indicated projections of earlier and reduced magnitude snowmelt-related seasonal flow peak in the upper Mekong Basin that are robust even in the presence of substantial uncertainty in future precipitation projections. It is likely that such changes (particularly in high and low flows) will have important implications for both the ecological and anthropogenic development of the Mekong River Basin.

Acknowledgements. This work was supported by a grant from the UK Natural and Environmental Research Council (NERC) awarded to the UCL Department of Geography (Taylor, Todd, Thompson) under the Quantifying and Understanding the Earth System (QUEST) programme (Ref. NE/E001890/1). ClimGen climate scenarios were generated by Tim Osborn at the Climatic Research Unit of the University of East Anglia. We are grateful for the constructive comments provided in the reviews by Guillaume Lacombe and Richard Taylor. Figure 1 was redrawn by Tracy Connolly (University of Otago).

Edited by: R. Taylor

\section{References}

Apaydin, H., Anli, A. S., and Ozturk, A.: The temporal transferability of calibrated parameters of a hydrological model, Ecol. Model., 195(3-4), 307-317, 2006.

Armstrong, R. N. and Martz, L. W.: Effects of reduced land cover detail on hydrological model response, Hydrol. Process., 22 2395-2409, 2008.

Arnell, N. W.: Effects of IPCC SRES* emissions scenarios on river runoff: a global perspective, Hydrol. Earth Syst. Sci., 7, 619641, doi:10.5194/hess-7-619-2003, 2003.

Arnell, N. W. and Osborn, T.: Interfacing climate and impacts models in integrated assessment modelling, Tyndall Centre for Climate Change Research Technical Report 52, 2006.

Bates, B. C., Kundzewicz, Z. W., Wu, S., and Palutikof, J. P. (Eds.): Climate Change and Water, Technical Paper of the Intergovernmental Panel on Climate Change, IPCC Secretariat, Geneva, Switzerland, 2008.

Christensen, J. H., Hewitson, B., Busuioc, A., Chen, A., Gao, X., Held, I., Jones, R., Kolli, R. K., Kwon, W. T., Laprise, R., Magaña Rueda, V., Mearns, L., Menndez, C. G., Räisänen, J., Rinke, A., Sarr, A. and Whetton, P.: Regional Climate Projections, in: Climate Change 2007: The Physical Science Basis. Contribution of Working Group 1 to the Fourth Assessment Report of the Intergovernmental Panel on Climate Change, edited by: Solomon, S., Qin, D., Manning, M., Chen, Z., Marguis, M., Averyt, K. B., Tignor, M. and Miller, H. L., Cambridge University Press, UK, 849-926, 2007.

Costa-Cabral, M. C., Richey, J. E., Goteti, G., Lettenmaier, D. P., Feldkötter, C., and Snidvongs, A.: Landscape structure and use, climate, and water movement in the Mekong River basin, Hydrol. Process., 22, 1731-1764, 2008.
Food and Agricultural Organisation of the United Nations (FAO): FAO-UNESCO Soil Map of the World: Revised Legend, World Soil Resources Report 60, FAO, Rome, Italy, 1990.

Hapuarachchi, H. A. P., Takeuchi, K., Zhou, M. C., Kiem, A. S., Georgievski, M., Magome, J., and Ishidaira, H.: Investigation of the Mekong River basin hydrology for 1980-2000 using the YHyM, Hydrol. Process., 22, 1246-1256, 2008.

Henriksen, H. J., Troldborg, L., Højberg, A. J., and Refsgaard, J. C.: Assessment of exploitable groundwater resources of Denmark by use of ensemble resource indicators and a numerical groundwater-surface water model, J. Hydrol., 348, 224-240, 2008.

Hughes, D. A., Kingston, D. G., and Todd, M. C.: Uncertainty in water resources availability in the Okavango River basin as a result of climate change, Hydrol. Earth Syst. Sci., 15, 931-941, doi:10.5194/hess-15-931-2011, 2011.

Hulme, M., Wigley, T. M. L., Barrow, E. M., Raper, S. C. B., Centella, A., Smith, S. J., and Chipanshi, A. C.: Using a Climate Scenario Generator for Vulnerability and Adaptation Assessments: MAGICC and SCENGEN Version 2.4 Workbook. Climatic Research Unit, Norwich UK, 52 pp., 2000.

Ishidaira, H., Ishikawa, Y., Funada, S., and Takeuchi, K.: Estimating the evolution of vegetation cover and its hydrological impact in the Mekong River basin in the $21^{\text {st }}$ century, Hydrol. Process., 22, 1395-1405, 2008.

Jain, S. K., Kumar, N., Ahmad, T., and Kite, G. W.: SLURP model and GIS for estimation of runoff in a part of Satluj catchment, India. Hydrol. Sci. J., 43,(6), 875-884, 1998.

Jayawardene, A. W. and Mahanama, S. P. P.: Meso-scale hydrological modelling: Application to Mekong and Chao Phraya basins, J. Hydrol. Eng., 7, 12-26, 2002.

Kiem, A. S., Geogievsky, M. V., Hapaurachchi, H. P., Ishidaira, H., and Takeuchi, K.: Relationship between ENSO and snow covered area in the Mekong and Yellow River basins, in Regional Hydrological Impacts of Climate Change - Hydroclimatic variability, edited by: Franks, S. W., Wagener, T., Bøgh, E., Bastidas, L., Nobre, C., and Galvão, C. O., IAHS Publ. 296, Wallingford, UK, 255-264, 2005.

Kiem, A. S., Ishidaira, H., Hapuarachchi, H. P., Zhou, M. C., Hirabayahi, Y., and Takeuchi, K.: Future hydroclimatology of the Mekong River basin simulated useing the high-resolution Japan Meteorological Agency (JMA) AGCM, Hydrol. Process., 22, 1382-1394, 2008.

Kim, B. S., Kim, H. S., Seoh, B. H., and Kim, N. W.: Impact of climate change on water resources in Yongdam Dam Basin, Korea, Stochastic Environmental Research and Risk Assessment, 21(4), 355-373, 2007.

Kingston, D. G. and Taylor, R. G.: Sources of uncertainty in climate change impacts on river discharge and groundwater in a headwater catchment of the Upper Nile Basin, Uganda, Hydrol. Earth Syst. Sci., 14, 1297-1308, doi:10.5194/hess-14-12972010, 2010.

Kingston, D. G., Todd, M. C., Taylor, R. G., and Thompson, J. R.: Uncertainty in the potential evapotranspiration climate change signal, Geophys. Res. Lett., 36, L20403, doi:10.1029/2009GL040267, 2009.

Kite, G.: The SLURP model, in Computer models of watershed hydrology by Singh, V.P. (ed.), Water Resources Publications, Colorado, USA, 521-562, 1995. 
Kite, G.: Modelling the Mekong: hydrological simulation for environmental impact studies, J. Hydrol. 253, 1-13, 2001.

Kite, G: Manual for the SLURP hydrological model version 12.7, HydroLogic-Solutions, 2008.

Kummu, M., Lu, X. X., Wang, J. J., and Varis, O.: Basin-wide sediment trapping efficiency of emerging reservoirs along the Mekong, Geomorphology, 119, 181-197, 2010.

Lacombe, G., Pierret, A., Hoanh, C. T., Sengtaheuanghoung, O., and Noble, A. D.: Conflict, migration and land-cover changes in Indochina: A hydrological assessment, Ecohydrology, 3, 382391,2010

Legates, D. R. and Willmott, C. J.: Mean seasonal and spatial variability in gauge-corrected, global precipitation, Int. J. Climatol., 10, 111-127, 1990.

Li, S. J. and He, D. M.: Water level response to hydropower development in the upper Mekong River, Ambio, 37, 170-177, 2008.

Lu, J. B., Sun, G., McNulty, S. G., and Amataya, D. M.: A comparison of six potential evapotranspiration methods for regional use in the southeastern United States, J. Am. Water Resour. As., 41, 621-633, 2005.

Meehl, G. A., Covey, C., Delworth, T., Latif, M., McAvaney, B., Mitchell, J. F. B., Stouffer, R. J., and Taylor, K. E.: THE WCRP CMIP3 Multimodel Dataset: A new era in climate change research, Bull. Am. Meteorol. Soc., 88, 1383-1394, 2007.

Mekong River Commission (MRC): State of the basin report: 2003, Mekong River Commission, Phomh Penh, ISSN: 1728:3248, 316 pp., 2003.

Mileham, L., Taylor, R. G., Thompson, J. R., Todd, M. C., and Tindimugaya, C.: Impact of rainfall distribution on the parameterisation of a soil-moisture balance model of groundwater recharge in equatorial Africa. J. Hydrol., 359, 46-58, 2008.

Mitchell, T. D. and Jones, P. D.: An improved method of constructing a database of monthly climate observations and associated high-resolution grids, Int. J. Climatol., 25, 693-712, 2005.

Murphy, J. M., Sexton, D. M. H., Barnett, D. N., Jones, G. S., Webb, M. J., Collins, M., and Stainforth, D. A.: Quantification of modelling uncertainties in a large ensemble of climate change simulations, Nature, 430, 768-772, 2004.

New, M., Hulme, M., and Jones, P. D.: Representing twentieth century space-time climate variability, Part I: Development of a 1961-1990 mean monthly terrestrial climatology, J. Clim., 12, 829-856, 1999

Park, G. A., Shin, H. J., Lee, M. S., Hong, W. Y., and Kim, S. J.: Future potential impacts of climate change on agricultural watershed hydrology and the adaptation strategy of paddy rice irrigation reservoir by release control, Paddy and Water Environment, 7(4), 271-282, 2009.

Randall, D. A., Wood, R. A., Bony, S., Colman, R., Fichefet, T., Fyfe, J., Kattsov, V., Pitman, A., Shukla, J., Srinivasan, J., Stouffer, R. J., Sumi, A., and Taylor, K. E.: Climate models and their evaluation, in Climate Change 2007: The Physical Science Basis. Contribution of Working Group 1 to the Fourth Assessment Report of the Intergovernmental Panel on Climate Change, edited by: Solomon, S., Qin, D., Manning, M., Chen, M., Marguis, M., Averyt, K. B., Tignor, M., and Miller, H. L., 589-662, Cambridge Univ. Press, Cambridge, UK, 2007.
Rango, A. and Martinec, J.: Revisiting the degree-day method for snowmelt conditions, Water Resour. Bull., 31, 657-669, 1995.

St. Laurent, M.: GIS-assisted hydrological modelling in the high boreal forest of northern Manitoba, M.S. Thesis, Department of Civil Engineering, University of Manitoba, Winnipeg, 2003.

Stone, R.: Along with Power, Questions Flow At Laos's New Dam, Science, 328, 414-415, 2010.

Su, M., Stolte, W. J., and van der Kamp, G.: Modelling Canadian prairie wetland hydrology using a semi-distributed streamflow model, Hydrol. Process., 14(14), 2405-2422, 2000.

Todd, M. C., Taylor, R. G., Osborn, T. J., Kingston, D. G., Arnell, N. W., and Gosling, S. N.: Uncertainty in climate change impacts on basin-scale freshwater resources - preface to the special issue: the QUEST-GSI methodology and synthesis of results, Hydrol. Earth Syst. Sci., 15, 1035-1046, doi:10.5194/hess-151035-2011, 2011.

Västilä, K., Kummu, M., Sangmanee, C., and Chinvanno, S.: Modelling climate change impacts on the flood pulse in the Lower Mekong floodplains, Journal of Water and Climate Change, 1, 67-86, 2010.

Viney, N. R., Bormann, H., Breuer, L., Bronstert, A., Croke, B. F. W., Frede, H., Graff, T., Hubrechts, L., Huisman, J. A., Jakeman, A. J., Kite, G. W., Lanini, J., Leavesley, G., Lettenmaier, D. P., Lindstrom, G., Seibert, J., Sivapalan, M., and Willems, P.: Assessing the impact of land use change on hydrology by ensemble modelling (LUCHEM) II: Ensemble combinations and predictions, Adv. Water Resour., 32(2), 147-158, 2009.

Vörösmarty, C. J., Federer, C. A., and Schloss, A. L.: Potential evaporation functions compared on US watersheds: Possible implications for global-scale water balance and terrestrial ecosystem modelling, J. Hydrol., 207, 147-169, 1998.

Wang, J. J., Lu, X. X., and Kummu, M.: Sediment load estimates and variations in the lower Mekong River, River Research and Application, 2009.

Warren, R., de la Nava Santos, S., Arnell, N. W., Bane, M., Barker, T., Barton, C., Ford, R., Füssel, H. M., Hankin, Robin K. S., Klein, R., Linstead, C., Kohler, J., Mitchel, T. D., Osborn, T. J., Pan, H., Raper, S. C. B., Riley, G., Schnellnhüber, H. J., Winne, S. and Anderson, D.: Development and illustrative outputs of the Community Integrated Assessment System (CIAS), a multiinstitutional modular integrated assessment approach for modelling climate change, Environ. Modell. Softw., 23, 592-610, 2008.

Woo, M. K., Long, T. Y., and Thorne, R.: Simulating monthly streamflow for the Upper Changjiang, China, under climatic change scenarios, Hydrol. Sci. J., 54, 596-605, 2009.

Xu, H., Taylor, R. G., Kingston, D. G., Jiang, T., Thompson, J. R., and Todd, M.: Hydrological modelling of the River Xiangxi using SWAT2005: a comparison of model parameterizations using station and gridded meteorological observations, Quatern. Int., 226, 54-59, 2010. 